\title{
Pictogram Extraction Algorithm for Local and Parallel Processing
}

\author{
Satoshi Iwakata Student Member (Keio University, iwakata@soft.ics.keio.ac.jp) \\ Daisuke Fujita Non-member (Keio University, fujita@soft.ics.keio.ac.jp) \\ Yoshiaki Ajioka Non-member (Ecchandes Inc., ajioka@cyberdoc.co.jp) \\ Masafumi Hagiwara Member (Keio University, hagiwara@soft.ics.keio.ac.jp)
}

Keywords: image processing, pictogram extraction, scenery image, local and parallel image processing, support for sight-restricted people

In this paper, we propose a pictogram extraction algorithm for local and parallel processing. Then, we show the example that the proposed algrithm is applied to lavatory mark detection. This algorithm works under a severe constraint: each pixel of a result image must be derived from only information of their neighbor pixels. This constraint is very important for a low cost device like a mobile camera because many other algorithms using grobal process can not be really carried out in such a device.

Fig. 1 shows our target device. It consists of many Processing Elements $(\mathrm{PE})$. This device can process images in parallel due to independency of PEs.

The proposed algorithm can estimate degree of square by pixel count method to extract pictograms. Fig. 2 shows the flow of the proposed algorithm. Fig. 3 shows examples of

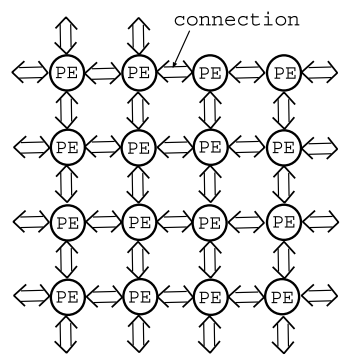

Fig. 1. Our target device

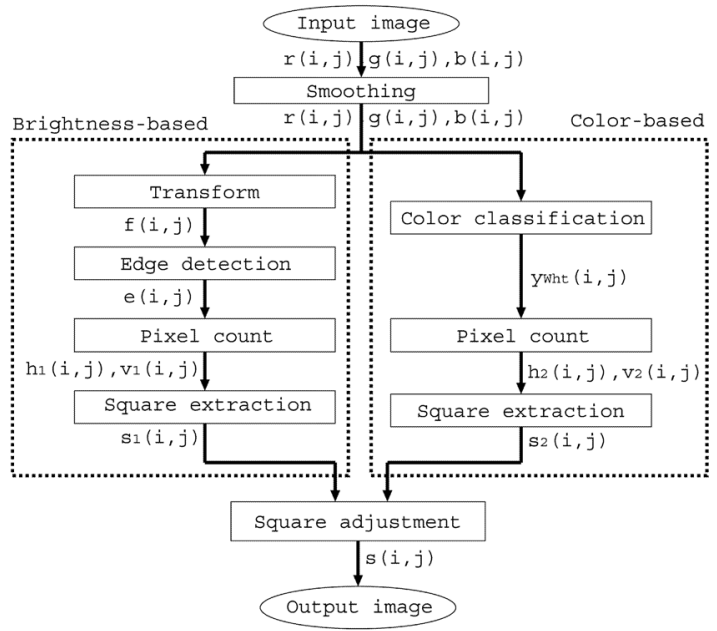

Fig. 2. Overview of the proposed system computer simulations. The result shows that the proposed algorithm can extract pictogram regions in a rate of more than $90 \%$, and false detection rate is less than $20 \%$.
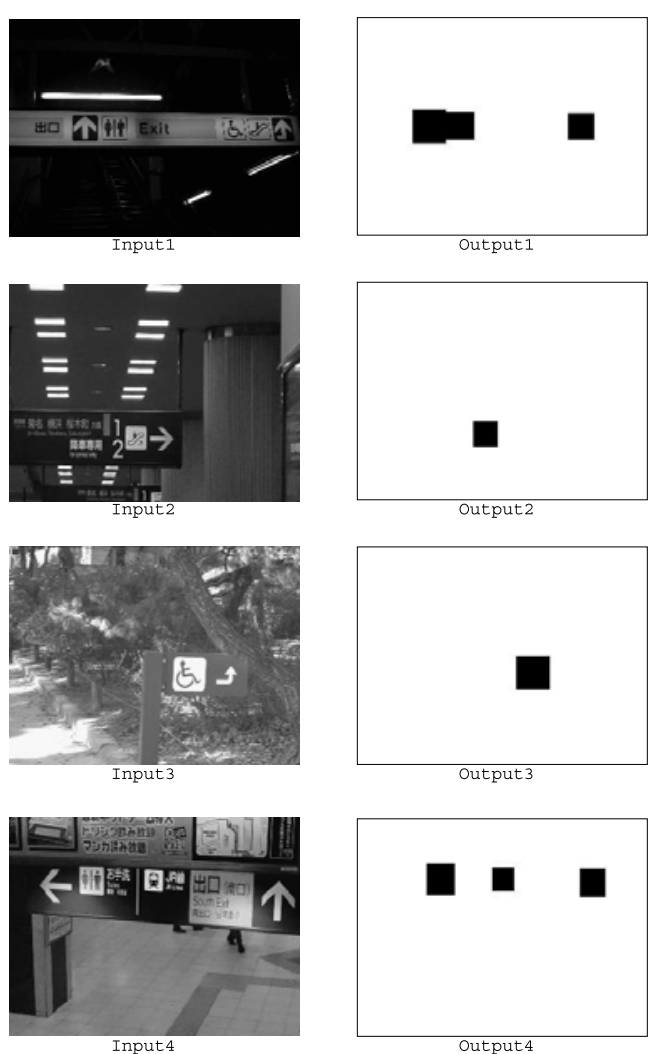

Fig. 3. Examples of computer simulations 


\title{
局所並列処理のためのピクトグラム抽出アルゴリズム
}

\author{
学生員 岩片 智* 非会員 藤田 大介* \\ 非会員 味岡 義明** 正 員 萩原 将文 ${ }^{*}$
}

\author{
Pictogram Extraction Algorithm for Local and Parallel Processing \\ Satohi Iwakata*, Student Member, Daisuke Fujita*, Non-member, Yoshiaki Ajioka**, Non-member, \\ Masafumi Hagiwara*, Member
}

In this paper, we propose a new pictogram extraction algorithm which consists of only local processings. The proposed algorithm preserves accuracy with simple and local processing instead of high cost and global processings. This approach is very important for parallel image processing by a low cost device, because each pixel can be processed in parallel. The proposed algorthm can estimate degree of square by pixel count method to extract pictograms. The proposed algorithm has been tested using 100 scenery images. The effectiveness has been confirmed from the results of the computer simulations.

キーワード：画像処理，ピクトグラム抽出，情景画像，局所並列画像処理

Keywords: image processing, pictogram extraction, scenery image, local and parallel image processing

\section{1. はじめに}

近年，視覚障害者支援を目的とする画像処理の研究が盛 んに行われている(1) (3)。ピクトグラム抽出も光の一つであ る。ピクトグラムとは, 意味するものの形状を使って , 乥 の意味概念を理解させる記号である。ピクトグラムは駅や ショッピングモールの中にあるトイレマークのように事前 の学習なしでも , 見ただけで誰にとってもすぐわかるとい う特徵を持っている。言語の違いというコミュニケーショ ンの壁や教育や年齡や経験の差を超えて，国際的，即時的 にわかる表現として注目を集めている。关の有効性は広く 認識され，多くの国で使用されている(4)(5)。

图 1 に本論文で対象とするピクトグラムの例を示す。ピ クトグラムのような図形や看板などを画像から抽出する研 究はあるが, 従来の手法は計算量が多いという問題点があ る (1) (6)。これらはデスクトップ PCなどで処理すれば処理 時間にはさほど問題はないが，視覚障害者支援等の用途で

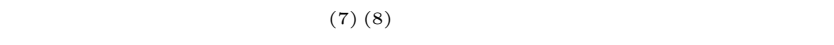
み込みハードウェアによる処理が適していると考えられる。

\footnotetext{
* 慶應義塾大学 理工学部

₹ 223-8522 横浜市港北区日吉 3-14-1

Keio University

3-14-1 Hiyoshi, Kohoku-ku, Yokohama 223-8522

** 株式会社 エッチャンデス

干 443-0057 愛知県蒲郡市中央本町 12-7

Ecchandes Inc.

12-7 Chuohonmachi, Gamagori, Aichi 443-0057
}
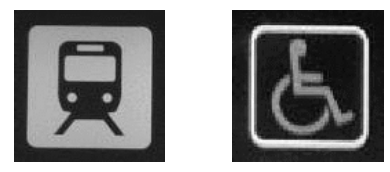

图 1 ピクトグラム例

Fig. 1. Examples of pictogram.

ハードウェア化により処理の高速化が可能であるが，従来 のアルゴリズムのハードウェア化は困難である。計算量が 多く, 大域的な処理や複雑な処理を必要とするからである。 乥うした中，味岡は「視覚装置」という新しい構成のビ ジョンチップを提案している ${ }^{(9)}(10)$ 。視覚装置は複数のプ ロセッシング・エレメント $(\mathrm{PE})$ が格子状に並んだ構成を

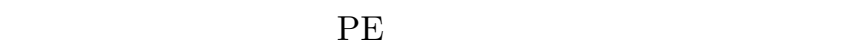
並列に処理することにより，高速な画像処理か実現できる。 各 PE は 4 近傍の PE とのみ物理的な接続を通して非同期 的に通信を行うが，順番にデータを転送することで論理的 にはより大きな近傍と通信を行うことも可能になっている。 また，PE はお互いに同期して連続して局所処理をするこ とができる。光のような処理を本論文では局所並列画像処 理と呼ぶことにする。この視覚装置の特長は低電力で並列 に動作することである。乥のため局所的な並列計算を高速 に行うことができる。局所並列画像処理を行うシステムの 大幅な小型化か実現可能であり，携帯電話への組み込みな どの用途でも大きな需要が見込まれる。

しかし，このような視覚装置の利点を活かすには，局所 
並列画像処理のみで完結するアルゴリズムの開発が不可欠 である。従来のようにフーリエ変換や八フ変換などを利用 するアルゴリズムやクラスタリングを用いるアルゴリズム などのように , 大域的な計算を必要とするアルゴリズムは 味岡か開発したような局所並列処理を行う視覚装置への実 装には適していない。

乥こで本論文では，注目画素の近傍の局所的な情報のみ を用いた処理によって情景画像からピクトグラムを抽出す る新しいアルゴリズムを提案する。なお，本論文で対象と するピクトグラムは四角形の枠に囲まれていることを前提 条件としている。

以下, 2 章ではピクトグラム抽出アルゴリズムについて 説明する。 3 章では光の応用例としてトイレマークを抽出 する手法を述べる。 4 章では計算機によるシミュレーショ ンを行い，弚の有効性を示す。 5 章で本論文をまとめる。

2. ピクトグラム抽出アルゴリズム

〈2: 1〉 概 要 图 2 にピクトグラム抽出アルゴリ ズムの流れを示す。提案アルゴリズムではまず，入力画像 に対し平滑化が行われる。兰の後，二通りの処理が行われ る。一方は輝度情報に基づく処理 (Brightness-based)，も う一方はカラー情報に基づく処理 (Color-based) である。 前者では輝度值に変換された後, エッジ検出が行われエッ ジのみの二值画像に変換される。後者では多色分類過程を 経て RGB の 3 帯域のカラ一画像が文献 (11) の方法により 白・黑・赤・青の 4 枚の二值画像に変換される。両過程とも

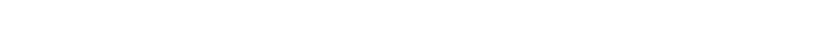
線分の長さの推定が行われ，四角形領域抽出過程でピク卜 グラム候補領域が抽出され，四角形領域補正過程で統合・ 判断され, 出力される。

〈2.2〉近傍定義 提案アルゴリズムはすべて局所並 列処理からなる。局所並列処理は各画素の近傍の情報を用 いて行われる。ここでは，弚のための近傍を定義する。画 像 $\boldsymbol{X}$ 中の位置 $(i, j)$ の画素値を $x(i, j)$ と表現する。 $(i, j)$ の $q$ 近傍集合 $P_{i, j}^{q}$ は近傍長 $r$ を用いて次式のように表さ れる。

$$
\begin{aligned}
P_{i, j}^{q}= & \{(l, m) \mid i-r \leq l \leq i+r, \\
& j-r \leq m \leq j+r,(l, m) \neq(i, j)\}
\end{aligned}
$$

すなわち $, r=1,2,3, \cdots$ のとき, $q=8,24,48 \cdots$ であ る。近傍数 $q$ は $r$ を用いて，以下のように表される。

$$
q=(2 r+1)^{2}-1 \text {. }
$$

なお，近傍集合 $P_{i, j}$ のうち画像サイズをはみ出した位置 $(l, m)$ の画素値 $x(l, m)$ には画像の端の画素値が代用され る。これにより，全ての画素において近傍数は等しくなる。 画像サイズをはみ出した位置 $(l, m)$ の代用画素值 $x(l, m)$ の位置 $l, m$ は，画像の縦横の座標を表すインデックス $l, m$

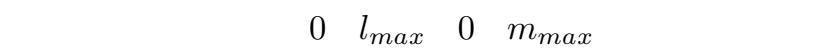
式で表される。

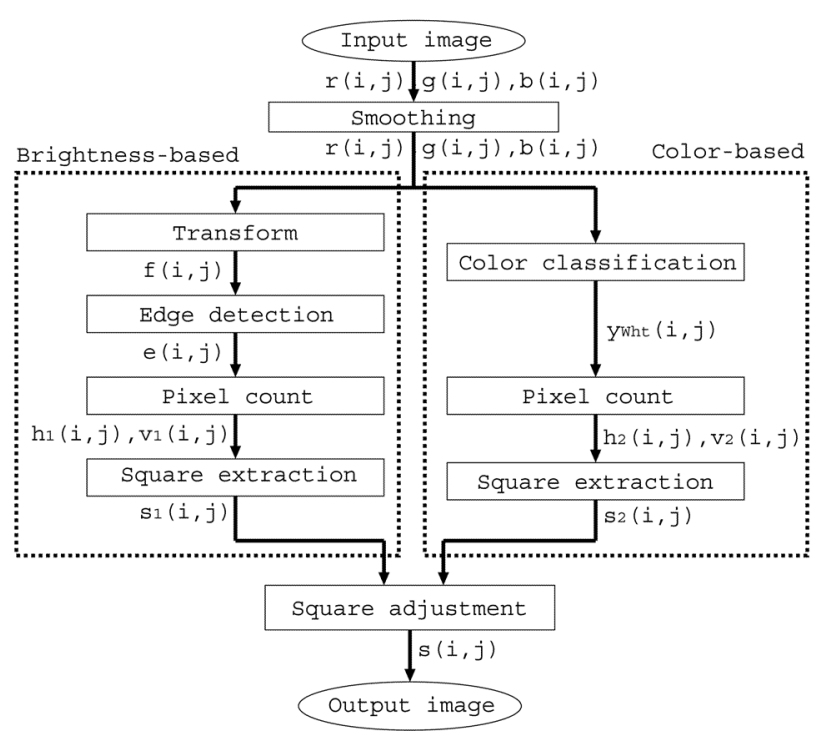

图 2 ピクトグラム抽出アルゴリズムの流れ

Fig. 2. Flow of the pictogram extraction algorithm.

$$
\begin{array}{ll}
l=0 & \text { if } l<0 \\
l=l_{\max } & \text { if } l>l_{\text {max }} \\
m=0 & \text { if } m<0 \\
m=m_{\max } & \text { if } m>m_{\max }
\end{array}
$$

〈2. 3〉平滑化過程 入力画像 $\boldsymbol{X}$ の画素値 $x(i, j)$ は 次式に従って平滑化され， $x^{\text {new }}(i, j)$ となる。

$$
x^{\text {new }}(i, j)=\frac{1}{q} \sum_{(l, m) \in \hat{P}_{i, j}^{q}} x(l, m) .
$$

式 (4)において ,

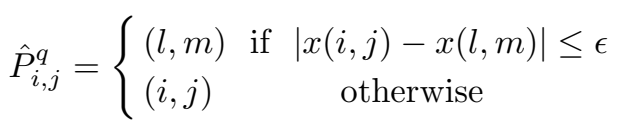

である。注目する画素との画素値の差が平滑化パラメータ $\epsilon$ を超える近傍画素值には，注目画素值が代入される。これに よりエッジ部分のように急に画素值か変化する部分では平滑 化が行われないようになる。このような平滑化を $x=r, g, b$ に対し数回繰り返し行う。

〈2. 4〉輝度值変換過程 提案アルゴリズムでは, 入力 画像の RGB 值は以下の式に従って輝度值に变換される。

$$
f(i, j)=0.3 \cdot r(i, j)+0.6 \cdot g(i, j)+0.1 \cdot b(i, j)
$$

〈2. 5〉 エッジ検出過程変換後の輝度画像 $\boldsymbol{F}$ に対し， ラプラシアンフィルタを用いてエッジ抽出を行う。エッジ 画像 $\boldsymbol{E}$ の各画素 $e(i, j)$ は, 輝度画像 $\boldsymbol{F}$ の各画素値 $f(i, j)$ を用いて次式のように表すことができる。

$$
\begin{cases}1 & \text { if }\left[8 \cdot f(i, j)-\sum_{(l, m) \in P_{i, j}^{8}} f(l, m)\right]>f(i, j) \\ 0 & \text { otherwise }\end{cases}
$$


〈2 6 7 多色分類過程 多色分類過程ではカラー画像か ら色の成分を抽出する。詳細な説明は文献 (11) に譲り要点 のみを述べる。 $k=\{r, g, b\}$ の 3 帯域の入力画像 $k(i, j)$ か ら，補色関係にある白色 $(W h t)$, 黑色 $(B l k)$, 赤色 $(R e d)$ 及び青色 $(B l u)$ の抽出を行う。このとき, 各補色関係は $q$ 近傍を用いて式 $(8)$ (11) のように計算される。

$$
\begin{aligned}
& d_{W h t}(i, j)=\max _{k}\left\{q \cdot k(i, j)-\sum_{k(l, m) \in P_{i, j}^{q}} k(l, m)\right\} \\
& d_{B l k}(i, j)=-\max _{k}\left\{q \cdot k(i, j)-\sum_{k(l, m) \in P_{i, j}^{q}} k(l, m)\right\} \\
& \text { …........... (9) } \\
& d_{\text {Red }}(i, j)=q\{r(i, j)-g(i, j)\} \\
& d_{B l u}(i, j)=-q\{r(i, j)-g(i, j)\}
\end{aligned}
$$

ここで式 (8) は白色らしさ, 式 (9) は黑色らしさ, 式 (10) は赤色らしさ，式 (11) は青色らしさを表している。

次に各色らしさにおいて , 值が最も高い画素を選択する。 $k=\{W h t, B l k, R e d, B l u\}$ の つの帯域に変換された二值 画像 $\boldsymbol{Y}_{k}$ の各画素 $y_{k}(i, j)$ は以下のように求められる。

$$
y_{W h t}(i, j)= \begin{cases}1 & \text { if } d_{W h t}(i, j)=\max _{k}\left\{d_{k}(i, j)\right\} \\ & d_{W h t}(i, j)>f_{1} \\ 0 \quad \text { otherwise }\end{cases}
$$

$$
y_{B l k}(i, j)= \begin{cases}1 \quad & \text { if } d_{B l k}(i, j)=\max _{k}\left\{d_{k}(i, j)\right\} \\ & d_{B l k}(i, j)>f_{2}, \\ & d_{B l k}(i, j) \neq d_{W h t}(i, j) \\ 0 \quad \text { otherwise }\end{cases}
$$

$$
y_{\text {Red }}(i, j)= \begin{cases}1 & \text { if } d_{\text {Red }}(i, j)=\max _{k}\left\{d_{k}(i, j)\right\} \\ & d_{\text {Red }}(i, j)>f_{3}, \\ & d_{\text {Red }}(i, j) \neq d_{W h t}(i, j), \\ & d_{\text {Red }}(i, j) \neq d_{B l k}(i, j), \\ 0 \quad \text { otherwise }\end{cases}
$$

$$
y_{B l u}(i, j)= \begin{cases}1 \quad & \text { if } d_{B l u}(i, j)=\max _{k}\left\{d_{k}(i, j)\right\} \\ & d_{B l u}(i, j)>f_{4} \\ & d_{B l u}(i, j) \neq d_{W h t}(i, j) \\ & d_{B l u}(i, j) \neq d_{B l k}(i, j) \\ & d_{B l u}(i, j) \neq d_{\text {Red }}(i, j) \\ 0 \quad \text { otherwise } & \end{cases}
$$

ここで, $f_{1} \sim f_{4}$ はしきい值である。この結果，式 $(12)$ によ り白色, 式 (13) により黑色, 式 (14)により赤色, 式 (15)に より青色であり光うな画素が選択される。式 (12)〜式 (15) は順序関係を持って定義されている。まず式 (12)，式 (13) で白黑の明度を基準に抽出し, 弚の後に式 (14), 式 (15) で
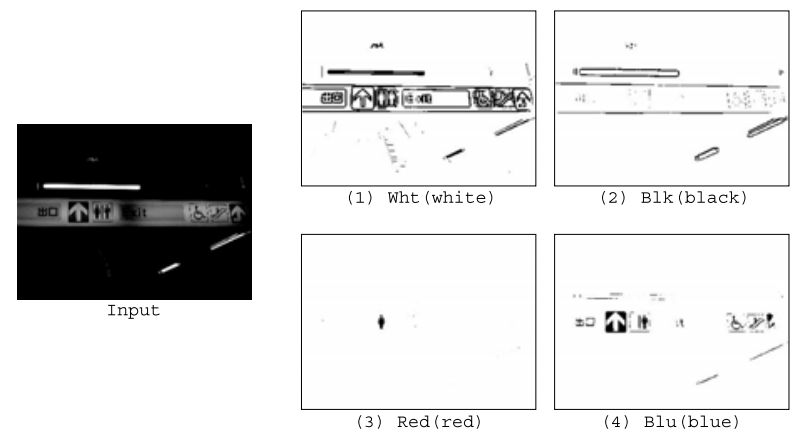

図 3 多色分類例

Fig. 3. An example of color classification.

色を抽出しようとしている。これは色の差よりも明度の差 の方が, 輪郭を抽出するのに重要であると考えられるから である。

式 (8)〜式 (15) によって, $\{r, g, b\}$ の 3 帯域の入力画像 は, $k=\{W h t, B l k, R e d, B l u\}$ の 4 帯域の 2 值画像 $\boldsymbol{Y}_{k}$ へ 変換される。変換後の各帯域では画素値は 0 または 1 の 2 值となる。多色分類した画像の例を図 3 に示す。本論文で 提案するピクトグラム抽出アルゴリズムにおいては，この うち Wht の帯域を利用する。これはピクトグラムの枠に は視認性を良くするため高いコントラストが存在するため である。Wht の帯域は周囲よりも明るい部分を抽出するの で, ピクトグラムの枠を抽出するのに適していると考えら れる。

〈2: 7〉 画素計数過程 ピクトグラムを構成する四角 形を推定するために，得られた二値画像 $\boldsymbol{Y}_{W h t}, \boldsymbol{E}$ から， 水平・垂直光れ光れの方向の線分の連結数を求める。

〈2: 7. 1 〉 初期 化座標 $(i, j)$ における水平方向 の連結画素数 $h_{1}(i, j), h_{2}(i, j)$, 垂直方向の連結画素数 $v_{1}(i, j), v_{2}(i, j)$ を以下の式に従い初期化する。

$$
\begin{aligned}
& h_{1}(i, j)=v_{1}(i, j)=e(i, j) \ldots \\
& h_{2}(i, j)=v_{2}(i, j)=y_{W h t}(i, j)
\end{aligned}
$$

ここでは, $h_{1}(i, j), \quad v_{1}(i, j)$ はエッジ画像 $\boldsymbol{E}$ 用であり $h_{2}(i, j), v_{2}(i, j)$ は多色分類後の画像 $\boldsymbol{Y}_{W h t}$ 用としている。

〈2:7· 2〉 水平方向連結数計数 水平方向連結数を数 える樣子を簡略化したものを図 4 に示す。図 4 は, 簡単の ため横方向一列分のみの画素の連結数の遷移を表したもの であり, 数字は各画素における連結数を表している。值を 持つ画素が炎の左の画素値と同じ值ならば連結数を増やし ている。

$k=1,2$ の $h_{k}(i, j)$ について以下の式を繰り返し , 水平 方向の連結数を数える。

$$
\begin{aligned}
& h_{k}(i, j)= \\
& \left\{\begin{array}{cc}
h_{k}(i, j)+1 & \text { if } \quad \max _{j-1 \leq m \leq j+1}\left\{h_{k}(i-1, m)\right\}=h_{k}(i, j) \\
& \text { and } h_{k}(i, j) \neq 0 \\
h_{k}(i, j) & \text { otherwise }
\end{array}\right.
\end{aligned}
$$




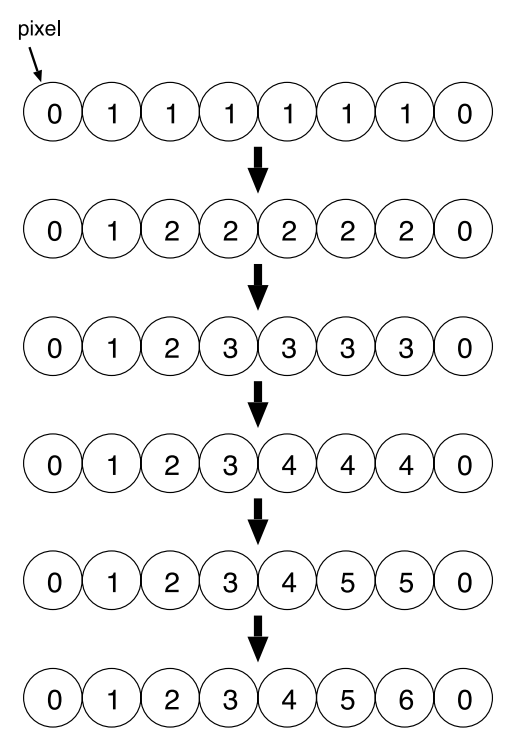

図 4 水平方向画素計数の樣子

Fig. 4. Procedure of pixel count.

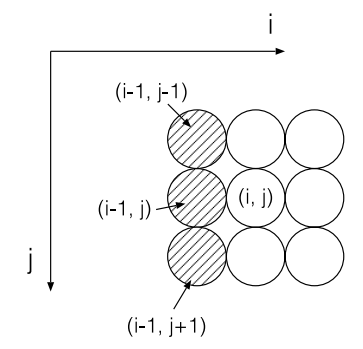

図 5 水平方向連結数計数のための参照画素

Fig. 5. Referencial pixels for horizontal pixel count.

式 (18) では, 注目画素が弚の左の画素値と同じ値ならば 連結数を増やす。 $h_{k}(i, j)$ は最初は 0 または 1 の二値画像 なので , 式 (18) を繰り返すことにより，一番右側の画素が 連結数を持つことになる。

また，ノイズや歪みなどに対応するため，图 5 に示すよ うに式 (18) では $m$ の定義域を $j-1 \leq m \leq j+1$ とする ことにより，斜め方向も考慮されている。图 5 では, 注目 画素を $(i, j)$ は左隣の画素 $(i-1, j)$ の他に , 光の上下の画 素 $(i-1, j-1)$ と $(i-1, j+1)$ を参照している。図中の 斜線部が参照画素を表している。

〈2. 7. 3 垂直方向連結数計数 水平方向連結数と同 樣に， $k=1,2$ である $v_{k}(i, j)$ について以下の式を繰り返 して垂直方向の連結数を数える。

$$
\begin{cases}v_{k}(i, j)= & \\ v_{k}(i, j)+1 & \text { if } \max _{i-1 \leq l \leq i+1}\left\{v_{k}(l, j-1)\right\}=v_{k}(i, j) \\ & \text { and } v_{k}(i, j) \neq 0 \\ v_{k}(i, j) & \text { otherwise }\end{cases}
$$

$$
\begin{aligned}
& h_{k}(i, j)= \\
& \left\{\begin{array}{l}
\max _{i-1 \leq l \leq i+1}\left\{h_{k}(l, j-1)\right\} \\
\text { if } \max _{\substack{i-1 \leq l \leq i+1 \\
\text { otherwise }}}\left\{v_{k}(l, j-1)\right\}=v_{k}(i, j) \\
h_{k}(i, j) \quad
\end{array}\right.
\end{aligned}
$$

式(19)では,式 (18) と同樣に注目画素が兴の上の画素值と

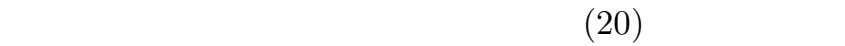
(18) で計算した水平方向の連結数を垂直方向に伝達する。

〈2. 8 > 四角形領域抽出過程 四角形領域抽出過程で は,前過程で得られた縦横弚れ光れの連結画素数を元に,正 方形に近い四角形かどうかの判断を行う。まず，以下の式 に従い $h_{1}(i, j), v_{1}(i, j)$ と $h_{2}(i, j), v_{2}(i, j)$ を用いて四角形 の一辺の長さ $a_{1}(i, j), a_{2}(i, j)$ の推定を行う。

$$
\begin{aligned}
& a_{k}(i, j)= \\
& \left\{\begin{array}{l}
\max \left\{h_{k}(i, j), v_{k}(i, j)\right\} \\
\text { if } \min \left\{h_{k}(i, j), v_{k}(i, j)\right\} / \max \left\{h_{k}(i, j), v_{k}(i, j)\right\} \geq t h_{a s p} \\
\text { and } \max \left\{h_{k}(i, j), v_{k}(i, j)\right\}>t h_{s} \\
0 \quad \text { otherwise }
\end{array}\right.
\end{aligned}
$$

式 (21) では, 求まった四角形の水平方向・垂直方向の連結 数の比が $h_{a s p}$ 以上であれば, 弚の領域を正方形とみなす。 またここでは, 連結数がしきい值 $t h s$ 以下の小領域の場合 はピクトグラムではない，あるいは確信度が低いとみなし 抽出しない。关の四角形領域の右下頂点にあたる画素 $(i, j)$ が正方形の一辺の長さ $a_{k}(i, j)$ を示すことになる。次に , 次 式に従い $a_{1}(i, j), a_{2}(i, j)$ を用いて四角形領域画像 $\boldsymbol{S}_{1}, \boldsymbol{S}_{2}$ の各画素 $s_{k}(i, j)$ の値を 1 にする。

$$
\begin{aligned}
& s_{k}(l, m \mid i-a(i, j) \leq l \leq i, j-a(i, j) \leq m \leq j)= \\
& \begin{cases}1 & \text { if } a_{k}(i, j)>t h \\
0 & \text { otherwise }\end{cases}
\end{aligned}
$$

〈2.9 9 四角形領域補正過程 まず, 以下の式に従い 二つの四角形領域抽出過程の出力 $S_{1}, S_{2}$ の和集合をとり， $S$ を得る。

$$
s(i, j)= \begin{cases}1 & \text { if } s_{1}(i, j)>0 \text { or } s_{2}(i, j)>0 \\ 0 & \text { otherwise }\end{cases}
$$

四角形領域抽出過程の出力は図 6(a)の中央や右の領域のよ うに複数の正方形が重なり，四角形が欠けたような形にな ることが多い。これは $\boldsymbol{Y}_{W h t}, \boldsymbol{E}$ に太さがあるからである。 これらは本来は一つの領域であるので, 以下の式に従い整 形する。

$$
s^{\text {new }}(i, j)=\left\{\begin{array}{l}
1 \quad \text { if } \quad s(i, j-1)=1 \\
\quad \text { and } s(i+1, j-1)=1 \\
\quad \text { and } s(i+1, j)=1 \\
0 \quad \text { otherwise }
\end{array}\right.
$$




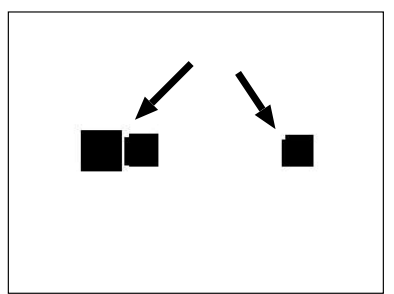

(a)

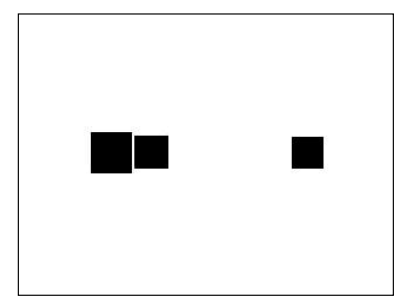

(b)
図 6 四角形領域補正過程の入出力

Fig. 6. An input and an output of square adjustment.

$s^{\text {new }}(i, j)=\left\{\begin{array}{cc}1 \quad & \text { if } \quad s(i-1, j)=1 \\ & \text { and } s(i-1, j-1)=1 \\ & \text { and } s(i, j-1)=1 \\ 0 \quad & \text { otherwise }\end{array}\right.$

$s^{\text {new }}(i, j)=\left\{\begin{array}{cc}1 \quad & \text { if } \quad s(i+1, j)=1 \\ & \text { and } s(i+1, j+1)=1 \\ & \text { and } s(i, j+1)=1 \\ 0 \quad \text { otherwise } & \ldots\end{array}\right.$

$s^{\text {new }}(i, j)=\left\{\begin{array}{cc}1 \quad & \text { if } \quad s(i-1, j)=1 \\ & \text { and } s(i-1, j+1)=1 \\ & \text { and } s(i, j+1)=1 \\ 0 \quad \text { otherwise } & \end{array}\right.$

式 (24)-式 (27) を繰り返すことにより，図 6(a) のような図 形は整形され，同図 (b) のような出力を得ることができる。

以上が本論文で提案するピクトグラム抽出アルゴリズム である。

\section{3. トイレマーク検出アルゴリズム}

〈3. 1〉 概 要 ここでは，前章で説明した部分を トイレマーク検出に適用したアルゴリズムを示す。図 7 に 本論文で対象とするトイレマークを示す。トイレマークに は，男女を表す色として赤と青が使用されていることが多 い。従って，ピクトグラム抽出アルゴリズムによって抽出 したピクトグラムのうち，これらの色を含む領域をトイレ マークとして検出する。図 8 に㫕の処理の流れを示す。こ のうち，ピクトグラム抽出過程 (pictogram extraction) は 前章で述べたピクトグラム抽出アルゴリズムである。多色 分類過程 (Color classification) において，Red 成分と Blu 成分を取り出し，关れ光れの成分のノイズを除去する。光 してピクトグラム抽出過程でえられた正方形領域 $S$ のう ち，赤色と青色を含む領域をトイレマークとして検出する。

〈3. 2〉多色分類過程本論文で提案するアルゴリズ 厶では， $\langle 2 \cdot 6\rangle$ 節で述べた多色分類結果のうち Red と Blu の 2 帯域を利用する。トイレマークには通常赤色と青色が

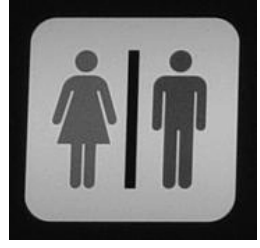

図 7 対象とするトイレマーク例

Fig. 7. An example of the lavatory mark.

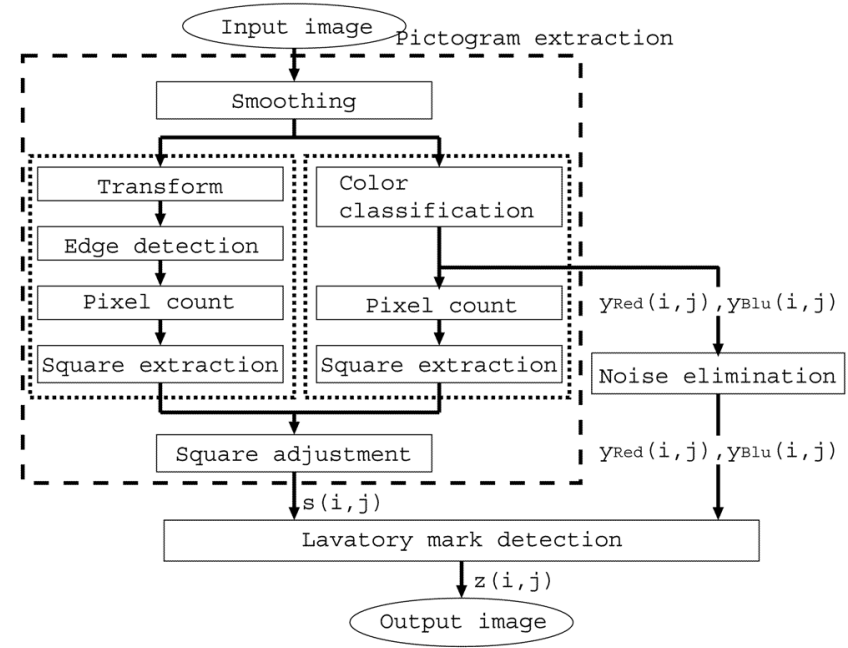

図 8 トイレマーク検出アルゴリズムの流れ

Fig. 8. Flow of the lavatory mark detection algorithm.

含まれているからである。

〈3. 3〉ノイズ除去過程ノノイ゙除去過程では次式に 従い, ノイズの除去・図形の整形を行う。

$$
y_{k}^{\text {new }}(i, j)= \begin{cases}1 & \text { if } \sum_{y_{k}(l, m) \in P_{i, j}^{8}} y_{k}(l, m) \geq 4, \\ 0 & \text { otherwise }\end{cases}
$$

式 (28) では, $k=\{R e d, B l u\}$ である。画素值が 1 の画素 において, 連結する画素が 3 つ以下の場合は, 兴の画素値 を 0 にするものである。この操作を 2 〜回行い, スポット ノイズを除去したり，抽出した図形の形を整えたりするこ とが可能である。

〈3. 4〉トイレマーク検出過程怆マーク検出過 程では, ノイズ除去過程の出力とピクトグラム抽出過程の 出力から, トイレマークを検出する。ピクトグラム抽出過 程で得られた四角形領域 $S$ の内 , ノイズ除去過程の出力の $R e d$ 成分と $B l u$ 成分が含まれる領域のみをトイレマーク領 域 $Z$ として検出する。まず，ピクトグラム抽出過程で得ら れたピクトグラム画像 $\boldsymbol{S}$ のうち, 内部に Red 成分が含まれ る領域のみを取り出し, $\boldsymbol{U}$ を生成する。 $\boldsymbol{U}$ の各画素 $u(i, j)$ は繰り返し回数を $t$ として以下の式により計算される。 
$u^{t+1}(i, j)=\left\{\begin{array}{l}1 \quad \text { if }\left(u^{t}(l, m) \mid(l, m) \in P_{i, j}^{8}\right)=1 \\ \quad \text { and } s(i, j)=1 \\ 0 \quad \text { otherwise }\end{array}\right.$

$u^{0}(i, j)= \begin{cases}1 & \text { if } y_{\text {Red }}(i, j)=1 \text { and } s(i, j)=1 \\ 0 & \text { otherwise }\end{cases}$

式 (29) を繰り返すことにより，Red 成分が含まれる四角形 領域を取り出す事ができる。

次に，UからさらにBlu 成分が含まれる四角形領域を抽 出し, 出力画像 $\boldsymbol{Z}$ を得る。 $\boldsymbol{Z}$ の各画素 $z(i, j)$ は繰り返し 回数を $t$ として以下の式により計算される。

$$
\begin{aligned}
& z^{t+1}(i, j)=\left\{\begin{array}{l}
1 \quad \text { if }\left(z^{t}(l, m) \mid(l, m) \in P_{i, j}^{8}\right)=1 \\
\quad \text { and } u(i, j)=1 \\
0 \quad \text { otherwise }
\end{array}\right. \\
& z^{0}(i, j)= \begin{cases}1 & \text { if } y_{B l u}(i, j)=1 \text { and } u(i, j)=1 \\
0 & \text { otherwise }\end{cases}
\end{aligned}
$$

式 (31) も式 (29) と同樣に繰り返し行う。

以上が本論文で提案するアルゴリズムのトイレマーク検 出への適用である。

\section{4. 計算機シミュレーション}

提案アルゴリズムの有効性を示すため, 情景画像を用い てピクトグラム及びトイレマークを抽出する計算機シミュ レーションを行った。

〈4 1〉 ピクトグラムの抽出 2 章で述べたピクトグラ ム抽出アルゴリズムを用い, 情景画像からピクトグラムを 抽出する計算機シミュレーションを行った。

〈4.1.1〉 シミュレーション条件通常のディジタル カメラで撮影した 256 階調，縦 480 画素 $\times$ 横 640 画素の カラー画像を使用した。画像は屋内外で撮影したものであ る。撮影時の天候は晴れまたは曇であり，日中あるいは夜 間に撮影した画像である。情景画像 100 枚の内，20 枚を表 1 に示すパラメータ設定のために使用し，残りの 80 枚を用 いて評価した。評価指標として, 抽出率と誤抽出率を次式 のように定義した。

$$
\text { 抽出率 }(\%)=\frac{\text { 抽出に成功した領域数 }}{\text { 画像に含まれるピクトグラム数 }} \times 100
$$

誤抽出率 $(\%)=\frac{\text { 抽出した非ピクトグラムの数 }}{\text { 抽出した領域数 }} \times 100$

$480 \times 640$ 画素の入力画像に対し，大きさが $40 \times 40$ 画素 以下のピクトグラムは抽出対象とはしていない。
計算機シミュレーションの条件を表 1 に示す。パラメー 夕值は予備実験により，最適と思われる值を設定した。

表 1 ピクトグラム抽出のパラメータ

Table 1. Parameters of pictocgram extraction.

\begin{tabular}{c||c}
\hline Parameter name & Value \\
\hline$q$ in equation(4) & 8 \\
\hline$\epsilon$ in equation(5) & 20 \\
\hline Times of smoothing & 7 \\
\hline$q$ in color classification & 120 \\
\hline$f_{1}$ in equation(12) & 1500 \\
\hline$f_{2}$ in equation(13) & 2000 \\
\hline$f_{3}$ in equation(14) & 1500 \\
\hline$f_{4}$ in equation(15) & 1500 \\
\hline$t h_{a s p}$ in equation(21) & 0.85 \\
\hline $\mathrm{th}_{\mathrm{s}}$ in equation(21) & 40 \\
\hline Times of square adjustment & 10 \\
\hline
\end{tabular}

表 2 ピクトグラム抽出結果

Table 2. A result of pictogram extraction.

\begin{tabular}{c|c}
\hline Extraction rate(\%) & False extraction rate(\%) \\
\hline 94.1 & 16.4 \\
\hline
\end{tabular}
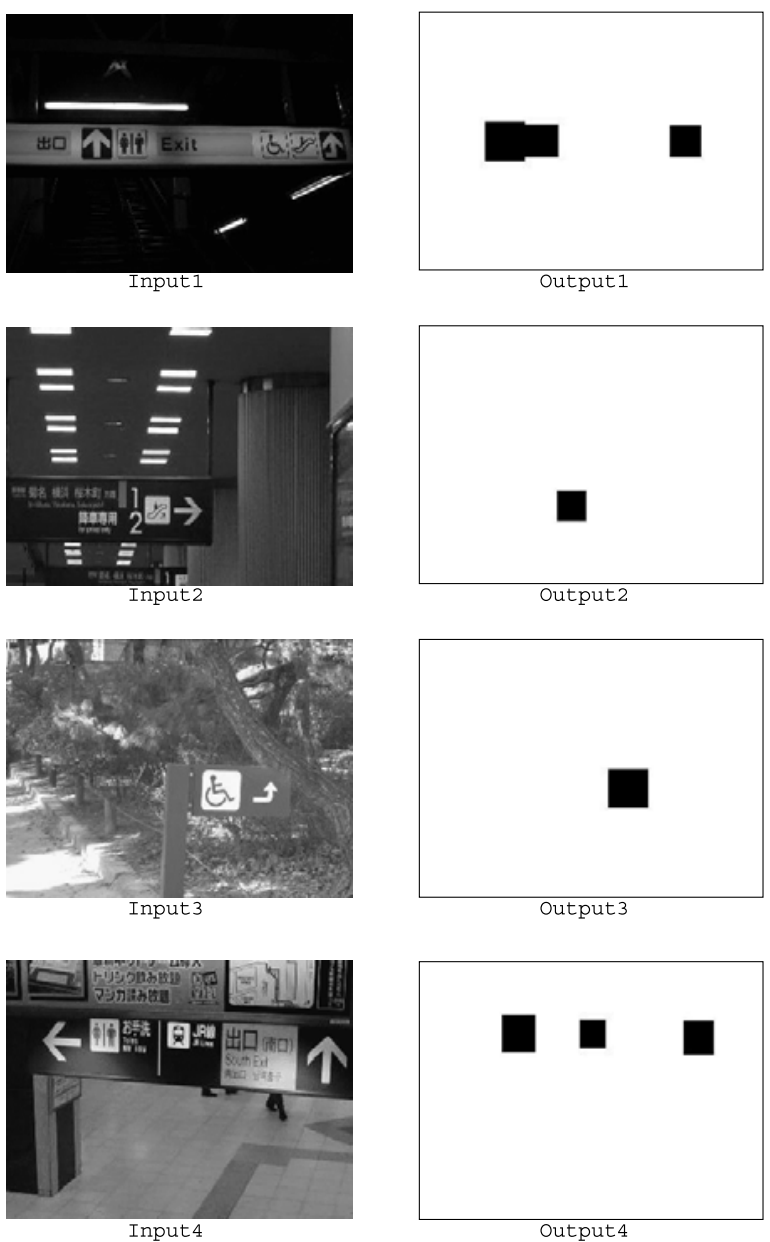

图 9 ピクトグラム抽出の入出力画像例

Fig. 9. Input and output examples of pictogram extraction. 

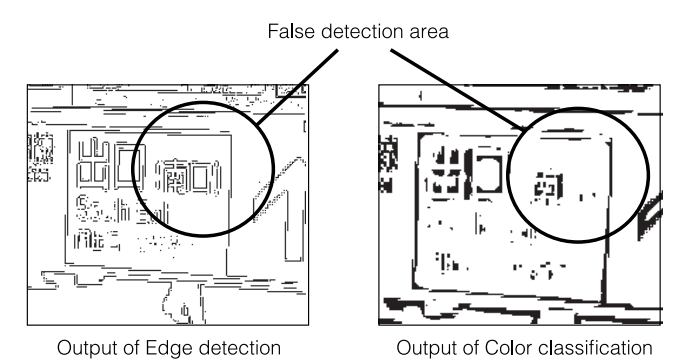

図 10 誤抽出の処理途中画像

Fig. 10. Images under processing.

表 3 ピクトグラムの大きさ別抽出率

Table 3. Extraction rate of size.

\begin{tabular}{l||c||c||c||c||c}
\hline Size (pixel on a side) & $40 \sim 60$ & $60 \sim 80$ & $80 \sim 100$ & $100 \sim 120$ & $120 \sim$ \\
\hline Exian
\end{tabular} \begin{tabular}{|l||c||c||c||c||c}
\hline Extraction rate (\%) & 97.1 & 93.8 & 91.3 & 98.0 & 93.0 \\
\hline
\end{tabular}

表 4 トイレマーク検出のパラメータ

Table 4. Parameter of lavatory mark detection.

\begin{tabular}{c|c}
\hline Parameter name & Value \\
\hline Times of noise elimination & 4 \\
\hline
\end{tabular}

表 5 トイレマーク検出結果

Table 5. A result of lavatory mark detection.

\begin{tabular}{c||c}
\hline Detection rate(\%) & False detection rate(\%) \\
\hline 84.0 & 4.5 \\
\hline
\end{tabular}

〈4·1·2〉 シミュレーション結果＼cjkstart表 2 に示すように 計算機シミュレーションの結果，抽出率は $94.1 \%$, 誤抽出 率は $16.4 \%$ であった。入出力画像の例を図 9 に示す。図 9

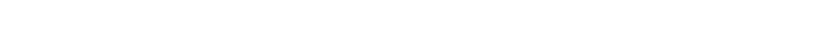
て抽出された領域が右側の図に示されている。図 9 からも 分かるように , 提案アルゴリズムではピクトグラムの地の 色によらず抽出することに成功している。一方で誤抽出率 はやや高めの值になっているが，二れは四角形領域抽出過 程において，歪みに対応するため正方形以外の图形を抽出 してしまうことが主な原因と考えられる。图 9 の一番目の 画像 (Input 1) では，画像中の右側にあるエスカレーター マークや矢印の抽出に失敗している。これはエッジ検出過 程においてエッジが切れてしまい, 多色分類過程において マークの枠と看板の外枠が連結してしまったためであると 考えられる。图 9 の一番下の画像 (Input 4) か誤抽出の例 である。これは入力画像の「出口」とかかれた領域の四角 形の右上部分を抽出してしまっている。該当部分のアルゴ リズム適用途中の拡大画像を図 10 に示す。图 10 は左側が エッジ画像，右側が多色分類後の二值画像 $\boldsymbol{Y}_{W h t}$ である。 該当部分はエッジがやや斜めになっており，图 10 の左側の ようにエッジが切れた状態で検出してしまったため，四角 形として誤抽出してしまったと考えられる。

計算機シミュレーションにおいてピクトグラムの大きさ 毎の抽出率を表 3 にまとめた。表 3 において, Size(pixel on a side) はピクトグラムの一辺の大きさを表す。例えば，
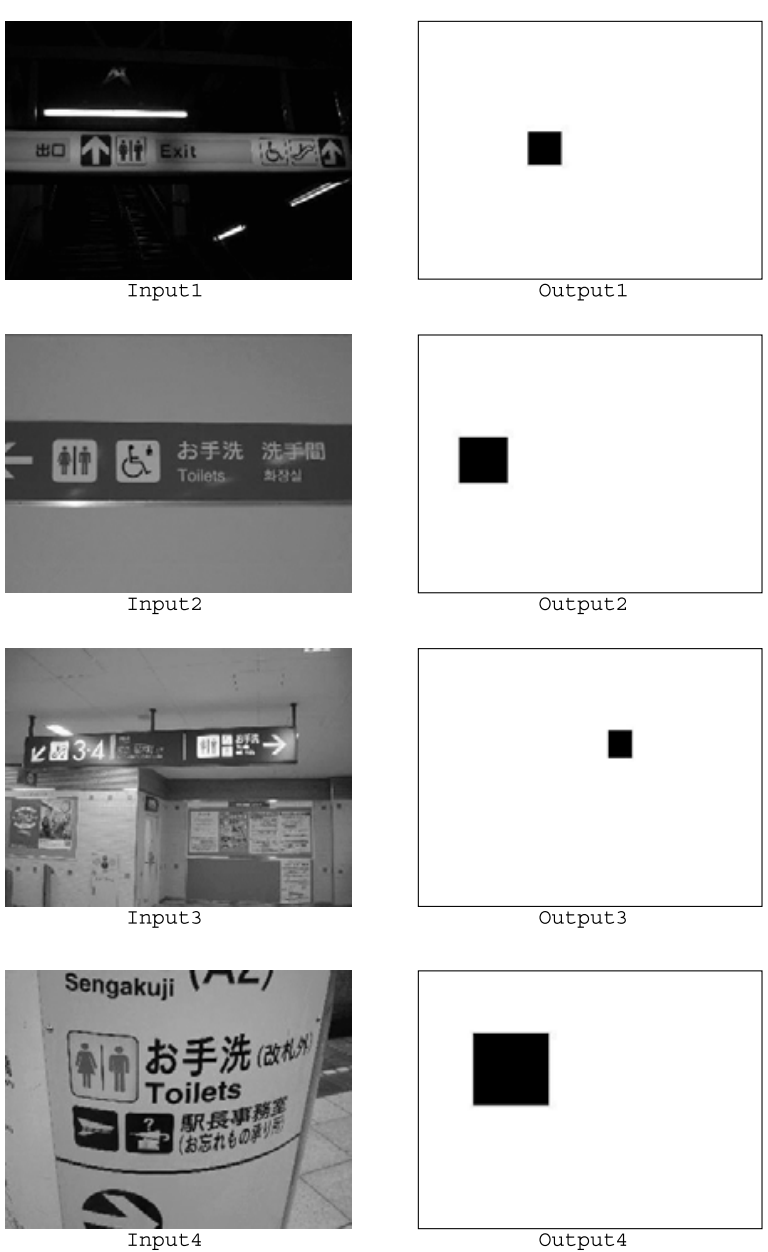

図 11 トイレマーク検出の入出力画像例

Fig. 11. Input and output examples of lavatory mark detection.

$40 \times 40$ ～ $70 \times 70$ のピクトグラムの抽出率が $96.0 \%$ である。 抽出率はいずれの大きさにおいても $90 \%$ を超えていること から，提案アルゴリズムでは四角形領域抽出過程において $t h_{s}$ によるしきい值処理で小さすぎる四角形領域を削除し ている以外では，抽出率はピクトグラムの大きさによらな いと考えられる。

〈4:2〉トイレマークの検出 3 章で述ベたトイレマー ク検出アルゴリズムを用い, 情景画像からトイレマークを 検出するシミュレーションを行った。

〈4. 2.1〉 シミュレーション条件 入力に用いた画像 や評価指標，ピクトグラム抽出過程のパラメータは $44 \cdot 1 \cdot 1\rangle$ 節と同じである。光の他のパラメータを表 4 のように設定 した。

〈4.2.2〉 シミュレーション結果結果を表 5 に示す。 また , 入出力画像の例を图 11 に示す。トイレマークの検出 においては, ピクトグラム検出結果に色による判定を加え る事により抽出条件を厳しくし，ピクトグラムの誤抽出率 を大幅に低下させることができたが, 抽出率もやや低下し た。特定のピクトグラムに特有の情報をさらに用いること により精度をさらに向上させる事が可能と考えられる。 


\section{5. まとめ}

本論文では局所的な処理のみで構成され並列化可能な， 新しいピクトグラム抽出アルゴリズムを提案した。

提案アルゴリズムは，視覚障害者の支援を前提に，すべ ての処理が局所計算のみで完結しており，ハードウェア化 に向いたアルゴリズムである。弚のため，対象画像が大き くなっても，PEの数を増やすことにより各 $\mathrm{PE}$ の計算量 を抑えることが可能である。

計算機シミュレーションにより，情景画像からピクトグラ ム領域を抽出できること，特定のピクトグラムに特化した 情報を使うことにより，効果的に特定のピクトグラムを検 出できることか確認された。今後は精度のみではなく, $\mathrm{PE}$ の計算量や通信量に関する評価が必要と考えられる。 (平成 17 年 2 月 22 日受付, 平成 17 年 9 月 26 日再受付)

\section{文献}

(1) T. Nagai, T. Kagehiro, M. Kaneko, and A. Kurematsu: "Text and Signboard Detection in Scene Images", IEICE Technical Report, CS2000-145, pp.103-108 (2001-3) (in Japanese)

長井隆行・影広達彦・金子正秀・榑松 明 : 情景画像中の文字及び 看板領域の抽出」，信学技報，CS2000-145, pp.103-108 (2001-3)

(2) F. Hang, T. Nagai, M. Kaneko, and A. Kurematsu: "Extraction of Characters on Signboards from Various Scene Images", IEICE Technical Report, IE2000-157, pp.13-18 (2001-1) (in Japanese)

傅 杭・長井隆行・影広達彦・金子正秀・榑松 明 : $\ulcorner$ 屋内外の情景 画像を対象とした看板文字の自動抽出」，信学技報，IE2000-157, pp.13-18 (2001-3)

( 3 ) H. Hiraiwa, Y. Takeuchi, T. Matsumoto, H. Kudo, Y. Liu, and N. Ohnishi: "A System Assisting the Visually Impaired People to Understand Character Information in the Environment", IEICE Technical Report, PRMU2001-269, pp.195-202 (2002-3) (in Japanese)

平岩裕康 - 竹内義則 - 松本哲也 . 工藤博章 - 劉 詠梅 - 大西 昇 「視覚障害者のための環境内の文字情報理解支援システム」, 信学技 報，PRMU2001-269, pp.195-202 (2002-3)

（4）村越愛策：「図記号のおはなし」，日本規格協会 (1987)

（5）太田幸夫：「ピクトグラムのおはなし」, 日本規格協会 (1995)

(6) D. Matsuura, H. Yamauchi, and H. Takahashi: "Extracting Circular Road Signs Using Specific Color Distinction and Region Limitation" IEICE Trans, Vol.J85-D-II, No.6, pp.10751083 (2002-6) (in Japanese)

松浦大祐・山内 仁・高橋浩光:「特定色判別と領域限定を用いた円形 道路標識の抽出」，信学論，J85-D-II, 6, pp.1075-1083 (2002-6

( 7 ) Y. Hu, T. Nagao, M. Okazaki, and T. Chinone: "Image Matching Process on Images Taken by a Cellular Phone", The Journal of the Institute of Image Information and Television Engineers, Vol.57, No.9, pp.1177-1186 (2003) (in Japanese)

胡 軼・長尾智晴・岡崎雅則・茅根大嗣:「カメラ付携帯電話で撮 影された画像のマッチング処理」, 映像情報メディア学誌, $\mathbf{5 7}, 9$ pp.1177-1186 (2003)

(8) M. Sawaguchi, K. Yamamoto, and K. Kato: "A proposal of character recognition method for low resolution images by using cellular phone", IEICE Technical Report, PRMU2002247 , pp.25-30 (2003-3) (in Japanese)

澤口元英・山本和彦・加藤邦人：「携帯電話における低解像度文字認 識手法の提案」, 信学技報, PRMU2002-247, pp.25-30 (2003-3)

(9) Y. Ajioka: "Visual Device", PCT, W000/16259 味岡義明：「視覚装置」, PCT 国際公開番号 WO00/16259

(10) Y. Ajioka, Y. Shimada, and H. Amano: "Size/Position detection algorithm on The Visual Device", IEICE Technical Report, VLD2001-135, CPSY2001-94, pp.23-30 (2002-1) (in Japanese)

味岡義明・嶋田雅洋・天野英晴:「視覚装置における位置/大きさ検出 アルゴリズムの検証」，信学技報，VLD2001-135, CPSY2001-94 (2002-1)

(11) S. Iwakata, Y. Ajioka, and M. Hagiwara: "Character Extraction Algorithm by Local and Parallel Processing", IEEJ Trans, EIS, Vol.124-C, No.4, pp.959-965 (2004-4) (in Japanese)

岩片 智・味岡義明・萩原将文：「局所並列処理による情景画像か らの文字抽出アルゴリズム」, 電学論 $(\mathrm{C}), \mathbf{1 2 4}, 4, \mathrm{pp} .959-965$ (2004-4)

(12) S. Iwakata, Y. Ajioka, and M. Hagiwara: "Thresholding Algorithm for Local and Parallel Processing", IEEJ Trans, EIS, Vol.125-C, No.4, pp.7-13 (2005-1) (in Japanese) 岩片 智・味岡義明・萩原将文 : 「局所並列処理のための二值化アル ゴリズム」, 電学論 $(C), \mathbf{1 2 5}, 1$, pp.7-13(2005-1)

岩 片

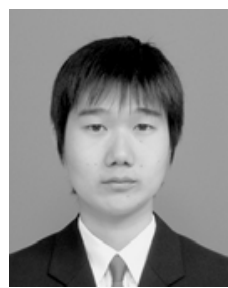

藤 田大介 (非会員) 2004 年慶大 ·理工 · 情報卒。2005 年

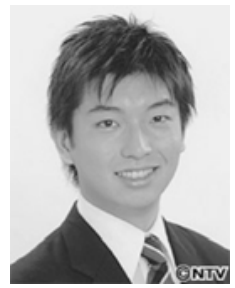

味 岡 義 明 (非会員) 1987 年慶大·理工・電気卒。1992 年同

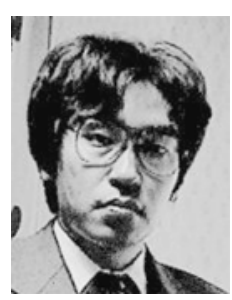
同大大学院修士課程中退。現在 , 日本テレビ放送 網（株）に勤務。写真 $=(\mathrm{C}) \mathrm{NTV}$ 大大学院博士課程了。博士 (工学)。1998 年エッ チャンデス代表取締役社長。盲導犬ロボットの研 究・開発に従事。
萩 原 将 文 (正員) 1982 年慶大·理工・電気卒。1 1987 年同大

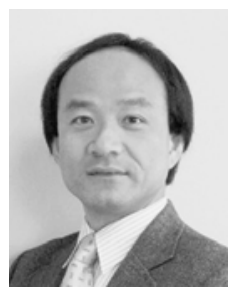
大学院博士課程了。工学博士。同年同大助手, 現 在 , 同大教授。1991 年より 2 年間アメリカ Stanford 大学訪問研究員。ニューラルネットワーク， ファジィシステム , GA の研究に従事。1986 年丹 羽記念賞, 1987 年電子情報通信学会学術奨励賞， 1990 年 IEEE 論文賞，1994 年安藤記念学術奨励 賞，1996 年ファジィ学会著述賞，2003 年日本感 性工学会技術賞, 2004 年同学会論文賞各受賞。IEEE シニアメンバ。 